\title{
Development of a Consumer Confidence Index for Pakistan: A Pilot Study on Three Main Urban Cities
}

\author{
Salma Mirza \\ Dr. Qazi Masood Ahmed
}

\begin{abstract}
What is meant by consumer sentiments index? What influences these indices? How should confidence indices be developed and how are they to be analyzed. And most importantly, how should an index for Pakistan be developed? These are the questions that have been focused in this study. The purpose of this pioneer study is to develop a reliable consumer confidence index for Pakistan and to plot test it on a small urban sample. The two most quoted indexes to measure consumer confidence in the US are the Michigan Consumer Sentiments Index (ICS) and the Consumer Confidence Index (CCl) published by the Conference Board. Based on these surveys, a unified scale was developed and tested for Pakistan. The findings for the survey are that, urban Pakistani citizens have very little confidence in the economy which includes sentiments about their own wellbeing as well as their expectations about the future.
\end{abstract}

Keywords: Consumer Confidence Index, Consumer Sentiments Index, Composite Indices, Urban Consumer Attitudes, Pakistan

\section{Introduction}

\subsection{Background}

Consumer confidence or sentiment refers to attitudes of optimism or pessimism with regards to general economic conditions of the time. These attitudes are what John Maynard Keynes has referred to as "animal spirits", which influence the real economy. (Ludvigson, 2004) All around the world, researchers and experts have endeavored to ascertain ways to measure this elusive concept that precedes or according to some experts, predicts spending. What is meant by consumer sentiments? How should they be measured? What exactly do the commonly found indices measure? What influences these indices? And what exactly does the index influence? These questions have been well debated and researched in the past and constitute the literature review of this paper.

The point, however, at which most analysts agree, is that consumer confidence indices are an essential albeit qualitative judgment about the state of the economy from the "factors of production" themselves and is a necessary ingredient to economic forecasts of today (Ludvigson, 2004). Therefore a number of other countries, following the US example, have initiated their own indices that they regularly publish and use for developing

Salma Mirza is an MS student at SZABIST, salma_mirza@hotmail.com Dr. Qazi Masood Ahmed is the Director, Business and Economic Research Center at the Institute of Business Administration, Karachi, qmasood@iba.edu.pk 
economic policies. The European Commission Directorate General, Economic and Financial Affairs (EC FIN) report on the Harmonized Consumer Survey, explicitly terms business and consumer surveys as an "indispensable tool" for "economic surveillance" of the EU. It also states that integration of consumer surveys is in line with the integration into the Union. The goal, therefore, of this paper is to develop a reliable survey scale for Pakistan, on the basis of which a consumer confidence index could be calculated on a periodic basis.

\subsection{Research Problem}

The purpose of this pioneer study is to develop a Consumer Confidence Index scale suitable for Pakistan after evaluating the $\mathrm{CCl}$ scales used around the world and pilot test it in three main cities of urban Pakistan.

\subsection{Research Questions}

- What is consumer confidence?

- How is it measured, and what are the commonly used scales to measure consumer confidence?

- How can these scales be used, either completely or with some modification, in the case of Pakistan?

- What is the current Consumer Confidence level of Pakistan?

\subsection{Significance of Study}

The information collected thus far on this topic reveals that there is no agreed upon measure to assess consumer confidence in Pakistan. There have been informal surveys to assess popular consumer sentiments by some foreign research organizations such as AC Nielsen. But these are conducted online, therefore excluding the masses in a country like Pakistan. The need at this stage is to establish a comprehensive tool to measure consumer confidence and to be able to continually gather data upon it for an extended period of time so that a longitudinal analysis could be made. The index will go a long way in establishing a benchmark on the basis of which popular sentiments could be recorded and provide an important variable upon which economic policy and its effectiveness could be measured.

\subsection{Scope}

The scope of this pilot study is limited to three main cities of Pakistan, namely, Karachi, Lahore and Islamabad. The fact that only urban areas have been targeted is due to the fact that the impact of common economic and financial indicators are felt and

\footnotetext{
1Details of the Survey can be found in European Economy Reports and Studies "The Joint Harmonized EU Programme of Business and Consumer Surveys User Guide" Updated 2004

${ }^{2}$ Survey results available periodically at www.acnielsen.com
} 
understood more by people living in the urban areas only. The rural economy of Pakistan is relatively fragmented, undocumented and quite divorced from urban economy. Besides this, all consumer surveys reviewed for this paper were conducted on the telephone, which is one of the fastest methods of data collection with the widest coverage (Zikhmund, 2000). Therefore the survey for this study was also conducted via telephone. In Pakistan, however, telephone line coverage in rural areas is patchy. Hence it is quite impossible to cover rural Pakistan at this time for a survey of this sort. Later, as this survey is adopted and conducted periodically by an organization, the methodology of covering rural Pakistan may be explored.

\subsection{Research Methodology}

The methodology of this survey was based on telephone interviews on an initial sample of approximately 500 people. The final decision on the size of the sample was based on sample size of Michigan University Survey of Consumers. Although the Conference Board assigns a sample of 5,000 consumers, for our purpose of conducting a pilot study, a sample of 500 was deemed appropriate, As with most telephone based interviews, the response rate was about $50 \%$, which brought the qualified responses to be about 250 people. The response rate surprisingly was reasonable as even in the case of the well known ICS the response rate is recorded to be no more than $70 \%$ (Curtin, 2002). The relatively small sample size need not be a source of major error. Curtin (2002) reports that survey results for two thirds of the final sample size of 500 is very accurate, having a correlation of 0.99 with the final measure. For the sampling frame, a PTCL numbers list was used. An independent research organization was contracted for the purpose of conducting telephone surveys. The PTCL numbers list has been rearranged and re-segmented on the basis of area and location. This enabled the interviewers to identify and validate to some extent the information provided to them by the respondents. The interviewers were trained for conducting the interviews before beginning the interview rounds.

\subsection{Sample}

The target population for the survey includes consumer living in Karachi, Lahore and Islamabad who are 18 or above. As discussed earlier, this population has been specifically targeted for its relevance to the study. We may find it useful to project the findings over the entire urban Pakistan considering the fact that these three cities are more or less representative of the entire discerning population of Pakistan. A final sample of size 250 was used for analysis. This included all people who were 18 years of age or above. The sampling methodology was random sampling.

\section{Literature Review}

Consumer confidence has been described in most literature as a qualitative judgment by the consumers in the state of the economy. De Boef and Kellstedt (2004) have described it as the way the understanding of objective economy is internalized and presented as subjective economy. This "subjective economy" can be attributed to how 
people view the state of their own well being as well as that of the economy. And this is also the elusive concept that is said to determine consumer spending. Pickering, Harrison and Cohen (1973) have argued that short term forecasting equations using long term objective macro economic variables have been ineffective in forecasting major turning points in consumer spending on durables as purchase of durables will be strongly influenced by "ebbs" and "flows" of consumer confidence.

Many authors on the topic have debated the question of what exactly does a consumer confidence index measure. The question that bothers most researchers is that should Consumer Confidence Index be taken only as a descriptor or reflector of current and short term future economic conditions or should it be taken as a predictor of major economic cycles. Most researchers are almost unanimous in their opinion that this index reflects the general macroeconomic conditions and encompasses the information included in the standard government statistics. (Desroches and Gosselin, 2004) But if it is only reflecting the information already available to us through other indicators, the question that arises here is then why do people in general and economists in particular set so much store in the $\mathrm{CCl}$. The strength of any indicator lies in its said ability to predict consumer spending. Interestingly, researchers are divided on the issue of predictive power of the index. There are authors, who after detailed analysis of the sentiment survey have concluded that the index has poor predictive ability. Roberts and Simon (2001) concludes that confidence and sentiment survey can only be useful for providing a qualitative commentary on the state of the economy. After detailed econometric analysis they suggest at the end of their paper that "Sentiment indicators can still be viewed as useful summary statistics complementary to an assessment of current conditions, but the extent to which they augment information already available to us should not be exaggerated." Fuhrer (1993) concludes that $70 \%$ of the variation in the ICS can be explained by variation in unemployment rate, national income, inflation and real interest rate.

Desroches and Gosselin (2004) concluded in their work that "consumer sentiment is a statistically important determinant of consumption in periods of high uncertainty, even after controlling for other determinants of consumption". In their work they used the consumption function and statistically eliminated the effects of explanatory variables such as income, unemployment rate, and inflation and concluded that about $72 \%$ of the variation in the index comes from the above stated variables (giving further credence to our aforementioned conclusion that consumer confidence reflects macroeconomic conditions and in a way follow major economic indicators). But it is the period of uncertainty that consumer sentiment is most likely to affect consumer spending. This view has been reiterated by many researchers. Indeed the user guide published by the DG ECFIN explicitly states that "there is an increasing interest in the use of economic surveys for predicting turning points in the economic cycle. Therefore business and consumer surveys are a necessary complement to quantitative statistical surveys, from which they differ in method and use". Federal Reserves chairman, Alan Greenspan, "a key determinant of near-term economic growth" (as quoted by Ludvigson, 2004). The two most quoted indexes to measure consumer confidence in the US are the Michigan Consumer Sentiments Index (ICS) and the Consumer Confidence Index (CCl) 
published by the Conference Board. The Michigan Consumer Sentiment index is computed from a monthly survey, called the Survey of Consumers, which consists of about 50 questions pertaining to consumer perceptions regarding economic climate in the country. The University Of Michigan Survey Of Consumers has a long history. After being established as an annual survey in the late 1940s it became a quarterly survey in 1952 and then became a monthly survey in 1978. Three separate indices are produced from this survey; Consumer Sentiment Index, Index of Consumer Expectations and Index of Current Economic Conditions. The leading Indicator Composite Index, produced by the US Department of Commerce includes the Index of Consumer Expectations. (Curtin, 2002) The other major index quoted in the context of consumer confidence is the Consumer Confidence Index published by the Conference Board. This index began in 1967 as a bi-monthly survey. Then from June 1977 the Conference Board started producing it as a monthly index. The Conference Board produces three indices; the Consumer Confidence Index, a Present Situation Index and the Expectations Index. (Duffy and Williams, 2002; Ludvigson, 2004)

In the EU, the consumer confidence survey is conducted by the EU Directorate of Economic and Financial Affairs (DG ECFIN) as part of the composite index, Economic and Sentiments Indicator (ESI) in the framework of the Joint Harmonized EU Programme of Business and Consumer Surveys. The surveys, which began in 1961, are carried out monthly by the DG ECFIN include industries, service, consumer, construction and retail trade. The consumer leg of the ESI was initiated in 1972 and was conducted on a quarterly basis in only 5 member states. (Duffy and Williams, 2002) At present the overall surveys are carried out by a number of public and private institutes and include 27 member states. The EU has harmonized the collection and calculation of the index across all member countries so as to have uniformity to allow for comparison of business cycles. Some of the EU member countries publish their own Consumer Confidence Indices, such as Ireland, in which the IIB Bank Consumer Confidence Index was conceptualized in 2002 and has since been referred to as a reliable confidence index for Ireland. (Benjamin, 2008).

\section{Analysis and Findings}

\subsection{Percentage Frequency Distributions}

This section contains question by question descriptive analysis. Simple frequency distributions have been calculated to analyze the data.

In the past 12 months, what monetary changes has your house experienced? (Pichle bara mahenon main aap ke ghar ke mali halat man kia tabdeli aai hai ?) 


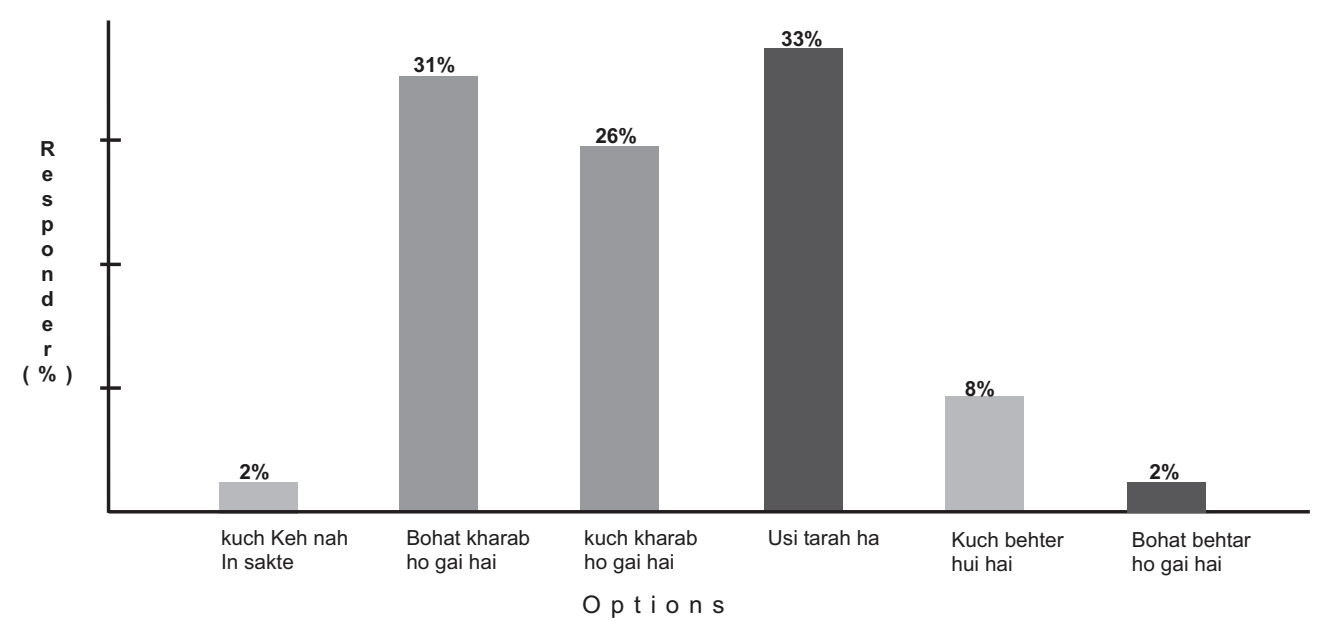

Figure No I

Around $60 \%$ of the respondents were dissatisfied with the financial conditions in their households. This question pertains to the present situation component of the scale. As shown above this presents a highly negative picture of the state of the economy and the way people view the situation. Only $10 \%$ of people asked had a positive response to this question.

In your opinion, what type of changes do you predict in the financial conditions of your house in the next 12 months?

Aap ke andaze main agle bara mahenon main aap ke gharane ki halat main kis tarah ki tabdeli ka imkan hai

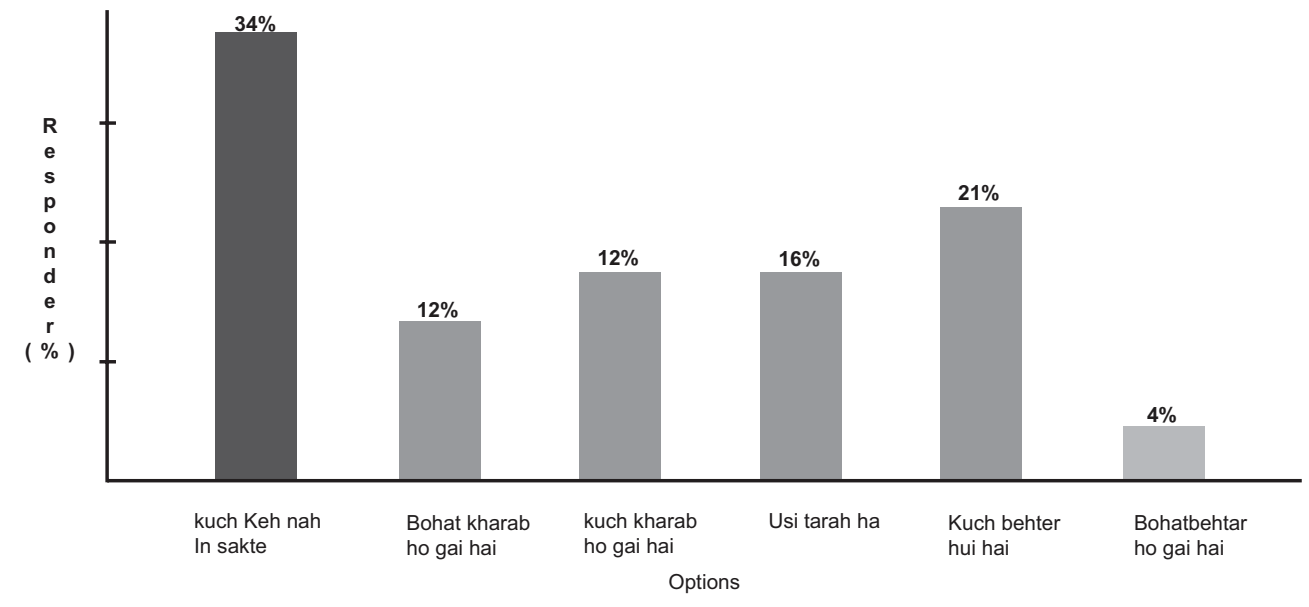

Figure No II

This question was one of the most important ones in the whole study as it revolved around the expectations component of the consumer confidence. A majority of people $(34 \%)$ responded in way that showed uncertainty about the future economic prospects. 
Also it must be noted that the statement if taken in the Urdu language connotation "Kuch Keh nahin sakte" has a negative bias. Therefore people who stated kuch keh nehin sakte actually stated it as a negative response instead of a neutral response. $12 \%$ stated that the situation is going to turn very bad. $16 \%$ stated that it would turn bad. Around $25 \%$ stated that they thought that things will improve.

As compared to the last 12 months, will you buy large expensive items more often in the next 12 months?

Pichle bara maheenon ke muqable main aap ainda bara mahenon main bari bari cheezen (maslan: furniture,bijli,electronic ka saman waghera) ziyada kharede jayen ge ya aam?

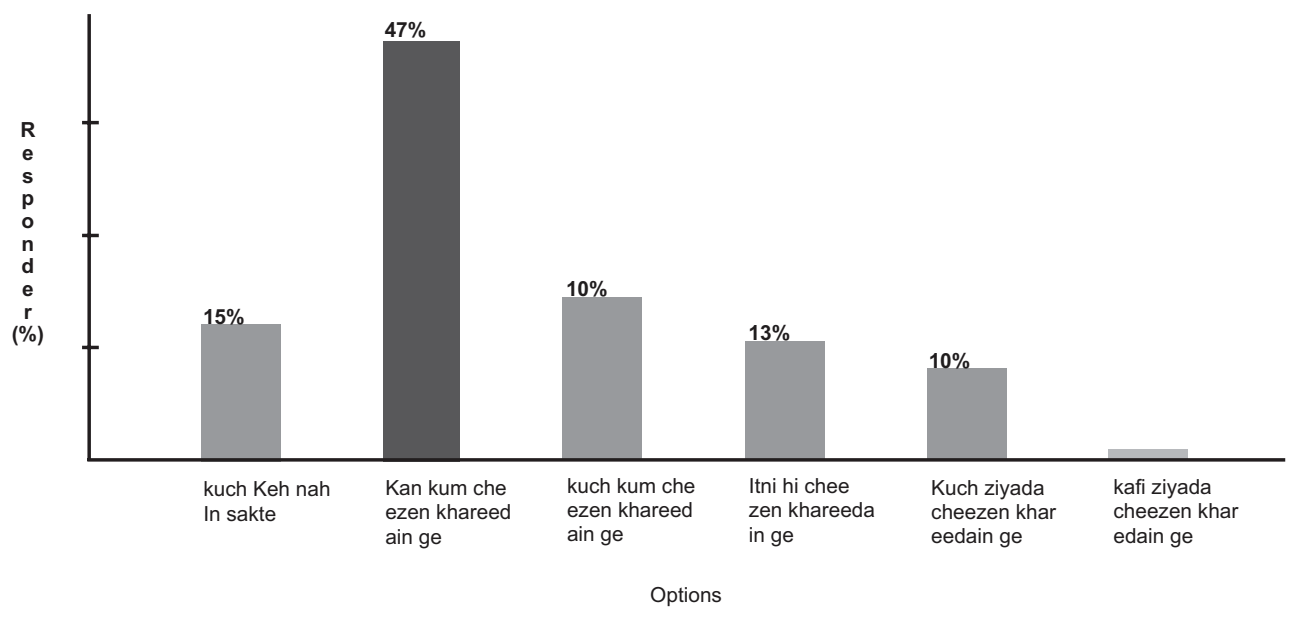

Figure No III

Around $65 \%$ of people interviewed for the survey indicated that they do not plan to purchase expensive and durable items in the next 12 months. This has huge implications on the expectations component and can forecast the kind of purchase behavior that is more in line with a recession. A small minority only about $12 \%$ recorded that they plan to buy discretionary spending on a large scale. This can still be explained by the fact that most people do discretionary spending cyclically and they may not be affected by the recessionary situation prevailing in the country.

Q-9: In your opinion, what economic changes has Pakistan undergone in the last 12 months?

Aap ke andaze main pichle bara mahenon main mulk ke muashi halat main kia tabdeli aai hai ? 


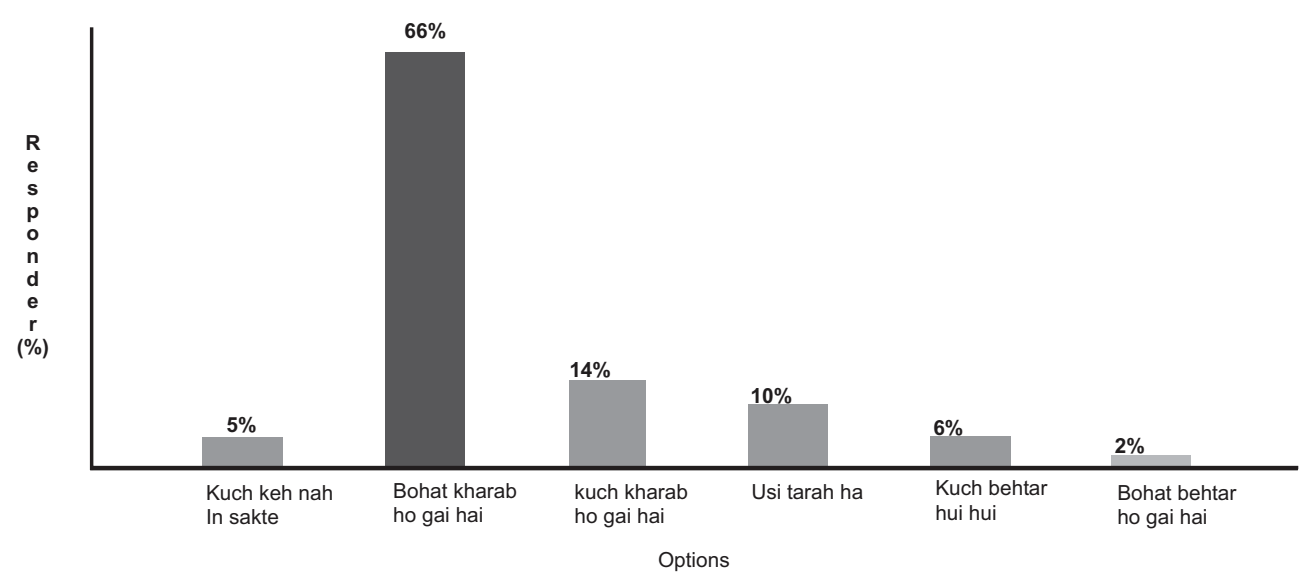

Figure No IV

This again is an eye-opening question. Around $80 \%$ of the people interviewed think that the country's economic situation has worsened not improved. This once again has implications for policy makers as well as economic manager. A tiny minority stated that things have improved a lot and a total of only $10 \%$ stated that things have stayed the same way as they were before.

Q-10: In your opinion, what economic changes will Pakistan undergo in the next 12 months?

Aap ke andaze main agle ane wale bara mahenon main mulk ke muashi halat main kis tarah ki tabdeli aye gi ?

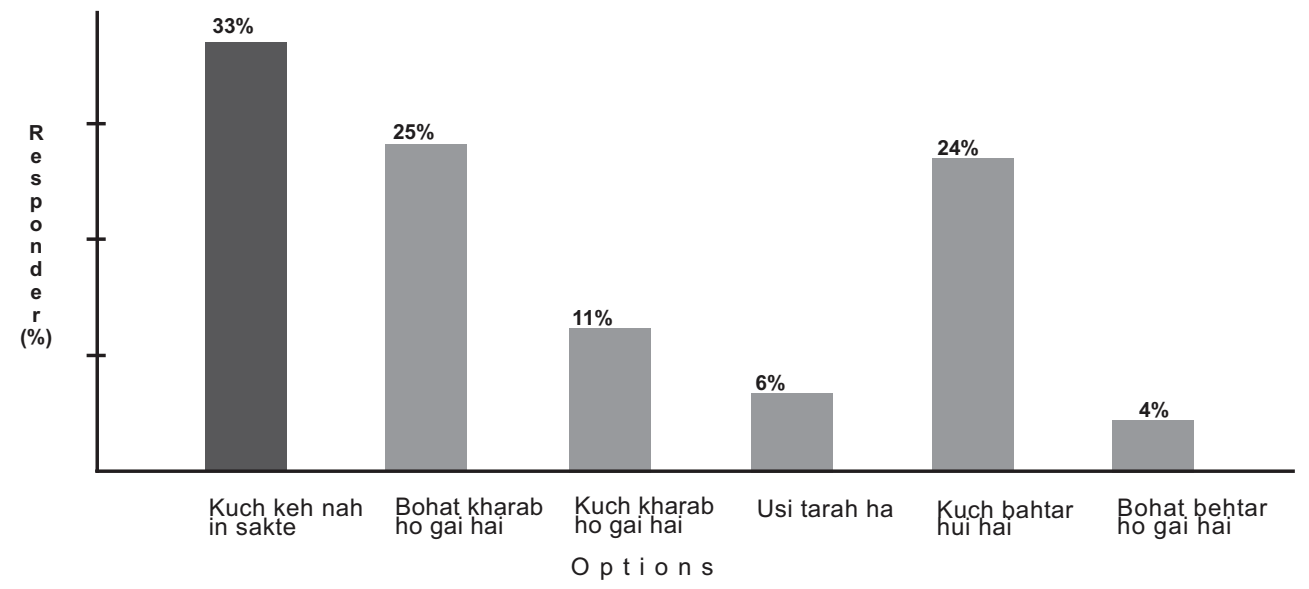

Figure No. V

This question belonged to the expectations component of the scale. As before a majority of people have expressed that they are uncertain about the future and therefore cannot comment upon what will happen next. As mentioned before it may be argued that the Urdu translation of "don't know" is not entirely free of a negative bias. Therefore you may argue that the people stated "kuch keh nahin sakte" actually gave a negative statement about their expectations about the future. 33\% expressed uncertainty about 
the future, whereas about $36 \%$ expressed a thoroughly negative stance to this question. Q-13: Aap ke andaze main agle bara mahenon main mulk main berozgar logon ki tadad kia ho gi ?

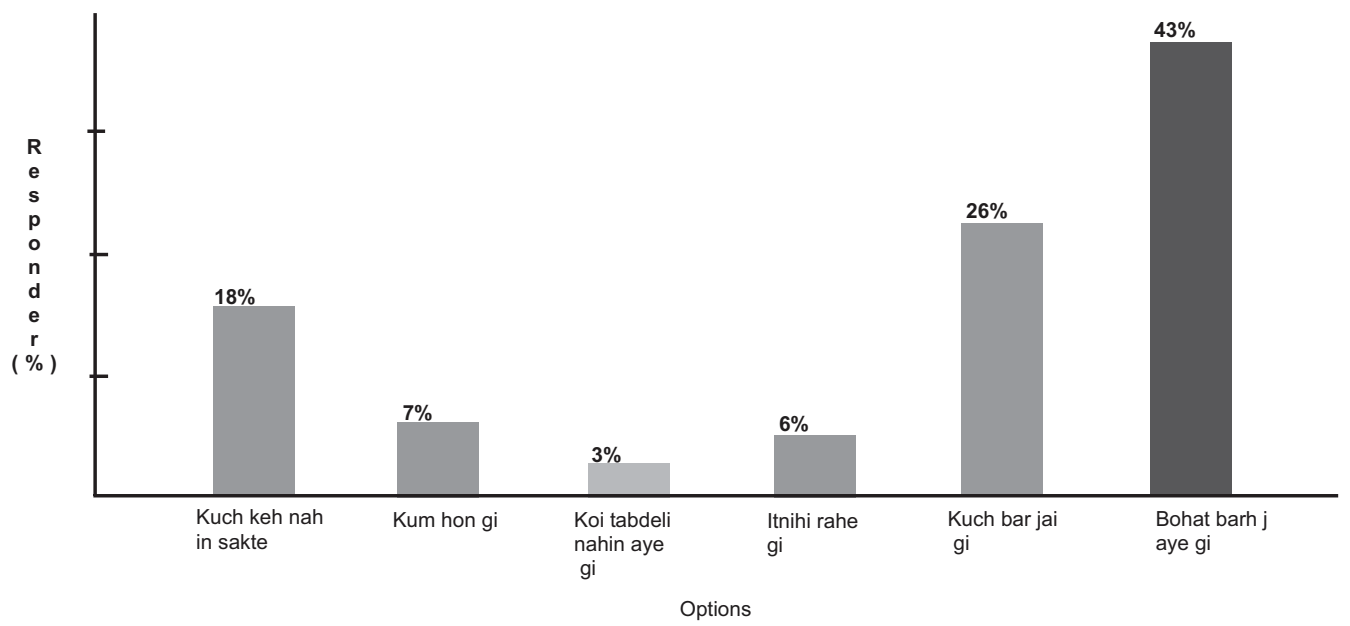

Figure No VI

In this question too people expressed distinctly their views regarding future expectations about the state of unemployment. A huge $70 \%$ respondent stated their expectations that the unemployment will rise. Therefore this question again has a negative judgment about the future expectations of people.

\subsection{Composite Index Calculations}

This section includes the calculation of the index based upon each of the questions and the response categories available. The formula used herewith is a simple weighted index calculation. In each question the neutral position or middle option is assigned a value of zero. This is to ensure that the index is based on opposite positions only. Weights of 1 and 0.5 are assigned to options that are very positive and positive respectively. Similarly weights of -1 and -0.5 are assigned to very negative and negative positions respectively. The aggregated score in each position is totaled after multiplying with the assigned weights and divided with the total count. A weighted average is thus calculated and subtracted from 1 to achieve the index for a particular question. The final index is simply an average of all the indices calculated earlier. The formula for item index is:

The formula for item index is:

Item Index=1-[ $[(\mathrm{W} \times \mathrm{C}) / \mathrm{C}]$

where $\mathrm{W}=$ Weight,

$\mathrm{C}=$ Count of responses

The calculated item indices are given in tabular form (with calculation) as under: 


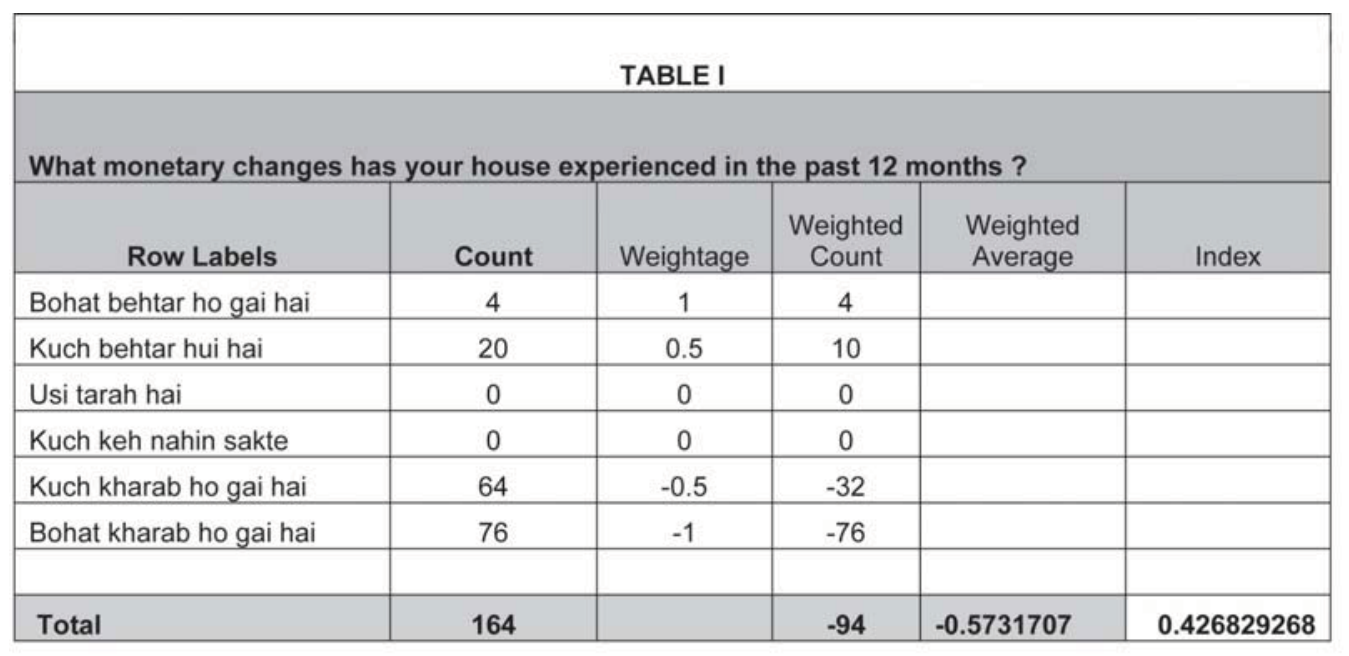

\begin{tabular}{|l|c|c|c|c|c|}
\hline \multicolumn{7}{|c|}{ TABLE II } \\
\hline \multicolumn{7}{|c|}{ What monetary changes do expect in your household in the next 12 montha } \\
\hline \multicolumn{1}{|c|}{ Row Labels } & Count & Weightage & $\begin{array}{c}\text { Weighted } \\
\text { Count }\end{array}$ & $\begin{array}{c}\text { Weighted } \\
\text { Average }\end{array}$ & Index \\
\hline Bohat behtar ho jai gi & 9 & 1 & 9 & & \\
\hline Kuch behtar ho jai gi & 52 & 0.5 & 26 & & \\
\hline Usi tarah rahe gi & 0 & 0 & 0 & & \\
\hline Kuch keh nahin sakte & 0 & 0 & 0 & & \\
\hline Kuch kharab ho jai gi & 40 & -0.5 & -20 & & \\
\hline Bohat kharab ho jai gi & 29 & -1 & -29 & & \\
\hline & & & & & \\
\hline Total & 130 & & -14 & $\mathbf{- 0 . 1 0 7 6 9 2 3}$ & $\mathbf{0 . 8 9 2 3 0 7 6 9 2}$ \\
\hline
\end{tabular}

\begin{tabular}{|c|c|c|c|c|c|}
\hline \multicolumn{6}{|c|}{ TABLE III } \\
\hline \multicolumn{6}{|c|}{ As compared to the last 12 months, will you buy more expensive items in the next 12 months? } \\
\hline Row Labels & Count & Weightage & $\begin{array}{l}\text { Weighted } \\
\text { Count }\end{array}$ & $\begin{array}{l}\text { Weighted } \\
\text { Average }\end{array}$ & Index \\
\hline $\begin{array}{l}\text { Kafi ziyada cheezen } \\
\text { kharedain ge }\end{array}$ & 2 & 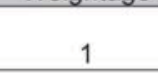 & 2 & & \\
\hline $\begin{array}{l}\text { Kuch ziyada cheezen } \\
\text { khareedain ge }\end{array}$ & 23 & 0.5 & 11.5 & & \\
\hline $\begin{array}{l}\text { Itni hi cheezen khareedain } \\
\text { ge }\end{array}$ & 0 & 0 & 0 & & \\
\hline Kuch keh nahin sakte & 0 & 0 & 0 & & \\
\hline $\begin{array}{l}\text { Kuch kum cheezen } \\
\text { khareedain ge }\end{array}$ & 43 & -0.5 & -21.5 & & \\
\hline $\begin{array}{l}\text { Kafi kum cheezen } \\
\text { khareedain ge }\end{array}$ & 117 & -1 & -117 & & \\
\hline Total & 185 & & -125 & -0.6756757 & 0.324324324 \\
\hline
\end{tabular}




\begin{tabular}{|l|c|c|c|c|c|}
\hline \multicolumn{7}{|c|}{ TABLE IV } \\
\hline \multicolumn{7}{|c|}{ What economic changes has Pakistan undergone in the past 12 months ? } \\
\hline Row Labels & Count & Weightage & $\begin{array}{c}\text { Weighted } \\
\text { Count }\end{array}$ & $\begin{array}{c}\text { Weighted } \\
\text { Average }\end{array}$ & Index \\
\hline Bohat behtar ho gai hai & 5 & 1 & 5 & & \\
\hline Kuch behtar hui hai & 11 & 0.5 & 5.5 & & \\
\hline Usi tarah hai & 0 & 0 & 0 & & \\
\hline Kuch keh nahin sakte & 0 & 0 & 0 & & \\
\hline Kuch kharab ho gai hai & 35 & -0.5 & -17.5 & & \\
\hline Bohat kharab ho gai hai & 165 & -1 & -165 & & \\
\hline \multicolumn{1}{|c|}{ Total } & $\mathbf{2 1 6}$ & & -172 & $\mathbf{- 0 . 7 9 6 2 9 6 3}$ & $\mathbf{0 . 2 0 3 7 0 3 7 0 4}$ \\
\hline
\end{tabular}

\begin{tabular}{|c|c|c|c|c|c|}
\hline \multicolumn{6}{|c|}{ TABLE V } \\
\hline \multicolumn{6}{|c|}{ What economic changes will Pakistan experience in the next 12 months? } \\
\hline Row Labels & Count & Weightage & $\begin{array}{l}\text { Weighted } \\
\text { Count }\end{array}$ & $\begin{array}{l}\text { Weighted } \\
\text { Average }\end{array}$ & Index \\
\hline Bohat behtar ho jai gi & 10 & 1 & 10 & & \\
\hline Kuch behtar ho jai gi & 58 & 0.5 & 29 & & \\
\hline Usi tarah rahe gi & 0 & 0 & 0 & & \\
\hline Kuch keh nahin sakte & 0 & 0 & 0 & & \\
\hline Kuch kharab ho jai gi & 26 & -0.5 & -13 & & \\
\hline Bohat kharab ho jai gi & 62 & -1 & -62 & & \\
\hline Total & 156 & & -93 & -0.5961538 & 0.403846154 \\
\hline
\end{tabular}

\begin{tabular}{|l|c|c|c|c|c|}
\hline \multicolumn{7}{|c|}{ TABLE VI } \\
\hline \multicolumn{7}{|c|}{ What changes have occurred in the prices of basic neccessity items in the last 12 months ? } \\
\hline \multicolumn{1}{|c|}{ Row Labels } & Count & Weightage & $\begin{array}{c}\text { Weighted } \\
\text { Count }\end{array}$ & $\begin{array}{c}\text { Weighted } \\
\text { Average }\end{array}$ & Index \\
\hline Koi tabdeli nahin aai & 0 & 0 & 0 & & \\
\hline Kuch nahin keh sakte & 0 & 0 & 0 & & \\
\hline Mamooli si bar gai hain & 10 & -0.5 & -5 & & \\
\hline $\begin{array}{l}\text { Mamooli se kuch kum hui } \\
\text { hain }\end{array}$ & 1 & 0.5 & 0.5 & & \\
\hline Bohat ziyada bar gai hain & 231 & -1 & -231 & & \\
\hline \multicolumn{1}{|c|}{ Total } & 242 & & -235.5 & $-\mathbf{0 . 9 7 3 1 4 0 5}$ & $\mathbf{0 . 0 2 6 8 5 9 5 0 4}$ \\
\hline
\end{tabular}




\begin{tabular}{|c|c|c|c|c|c|}
\hline \multicolumn{6}{|c|}{ TABLE VII } \\
\hline \multicolumn{6}{|c|}{ What changes will occur in the prices of basic neccessity items in the next 12 months? } \\
\hline Row Labels & Count & Weightage & $\begin{array}{c}\text { Weighted } \\
\text { Count }\end{array}$ & $\begin{array}{l}\text { Weighted } \\
\text { Average }\end{array}$ & Index \\
\hline Kum hon gi & 14 & 1 & 14 & & \\
\hline Koi tabdeli nahin aye gi & 0 & 0 & 0 & & \\
\hline Is se kum raftar se barhain gi & 22 & 0.5 & 11 & & \\
\hline Kuch keh nahin sakte & 0 & 0 & 0 & & \\
\hline Isi raftar se barhain gi & 89 & -0.5 & -44.5 & & \\
\hline Bohat Tezi say barhain gi & 56 & -1 & -56 & & \\
\hline Total & 181 & & -75.5 & -0.4171271 & 0.582872928 \\
\hline
\end{tabular}

\begin{tabular}{|l|c|c|c|c|c|}
\hline \multicolumn{7}{|c|}{ TABLE VIII } \\
\hline \multicolumn{2}{|c|}{ What will be the level of unemployment in Pakistan in the next 12 months ? } \\
\hline Row Labels & Count & Weightage & $\begin{array}{c}\text { Weighted } \\
\text { Count }\end{array}$ & $\begin{array}{c}\text { Weighted } \\
\text { Average }\end{array}$ & Index \\
\hline & & & & & \\
\hline Kum hon gi & 16 & 1 & 16 & & \\
\hline Itni hi rahe gi & 19 & 0.5 & 9.5 & & \\
\hline Kuch keh nahin sakte & 0 & 0 & 0 & & \\
\hline Kuch bar jai gi & 65 & -0.5 & -32.5 & & \\
\hline Bohat barh jaye gi & 108 & -1 & -108 & & $\mathbf{0 . 4 4 7 1 1 5 3 8 5}$ \\
\hline \multicolumn{1}{|c|}{ Total } & 208 & & -115 & $\mathbf{- 0 . 5 5 2 8 8 4 6}$ & \\
\hline
\end{tabular}

\begin{tabular}{|c|c|c|c|c|c|}
\hline \multicolumn{6}{|c|}{ TABLE IX } \\
\hline \multicolumn{6}{|c|}{$\begin{array}{c}\text { Count of in the light of Pakistan's economic conditions, do you feel that it is the appropriate time to } \\
\text { buy large and expensive items ? }\end{array}$} \\
\hline Row Labels & Count & Weightage & $\begin{array}{l}\text { Weighted } \\
\text { Count }\end{array}$ & $\begin{array}{l}\text { Weighted } \\
\text { Average }\end{array}$ & Index \\
\hline $\begin{array}{l}\text { Haan ye bilkul munasib } \\
\text { waqt hai }\end{array}$ & 26 & 1 & 26 & & \\
\hline $\begin{array}{l}\text { Na ye waqt munasib hai } \\
\text { nag hair munasib }\end{array}$ & 0 & 0 & 0 & & \\
\hline Kuch keh nahin sakte & 0 & 0 & 0 & & \\
\hline $\begin{array}{l}\text { Nahin ye munasib waqt } \\
\text { nahin }\end{array}$ & 165 & -1 & -165 & & \\
\hline Total & 191 & & -139 & -0.7277487 & 0.272251309 \\
\hline Composite Index & & & & & 0.39779 \\
\hline
\end{tabular}




\section{Conclusion/Policy Implications}

- $\quad$ The conclusion of this work can be divided into two parts. One related to the actual construction/calculation of the index and the other related to the findings of the survey. The purpose of the research was to construct a meaningful scale and construction method of the index relevant to Pakistan. By pilot testing, this researcher was able to also observe the practicality of such an endeavor, if done on a regular basis. Indeed, this objective has been achieved. The pilot study showed that the survey of consumer sentiments is quite doable in Pakistan. However it may be pointed out that the scale must be modified in line with the findings given further under this heading, as some scale items are redundant or confusing or both to the respondents.

- $\quad$ The index tables given above may be analyzed insofar as the computation formula is concerned. The actual results/indexes can only be reasonably analyzed longitudinally when data is available for at least a year. Without longitudinal data, the index values will have little bearing one way or the other. This means that the final index value of 0.39779 explains consumer sentiments only when descriptive analysis is kept in focus. Any other form of analysis requires a time series data.

- It is also not suitable for us to compare indices across countries as each country has a different method of data collection and a different scale. Therefore at this point in time the data has been presented as a first survey result, which has been analyzed descriptively. Also index tables have been constructed to present how the index values will be calculated. Any other meaningful analysis can only be provided once the survey is conducted periodically and regularly.

- When analyzing the frequency tables we see that the findings are two- fold. One, urban Pakistani citizens have very little confidence upon the economy which includes sentiments about their own wellbeing as well as their expectations about the future. The second important finding revolves around the data validating commonly understood concepts about the index; the index reflects prevalent conditions of the economy to a very large extent. Therefore this helps us to conclude that this index represents consumer sentiments appropriately and can be used as a good tool in the future as a commentary upon the general economic conditions of the society.

- As far as personal financial conditions are concerned, $60 \%$ of the respondents were dissatisfied with the financial conditions in their households. The question that pertains to the present situation component of the scale drew a negative response. This present a highly negative picture of the state of the economy and the way people view the situation. Only $10 \%$ of people who were asked had a positive response to this question.

- A majority of people (34\%) responded expressed uncertainty about the future economic prospects. It must also be noted that the statement if taken in the Urdu language connotation "Kuch Keh nahin sakte " has a negative bias. Therefore people who stated kuch keh nehin sakte actually stated it as a negative response instead of a neutral response. $12 \%$ stated that the situation is going to turn very 
bad. $16 \%$ stated that it would turn bad. Around $25 \%$ stated that they thought that things will improve.

- $\quad$ Around $80 \%$ of the people interviewed thought that the country's economic situation has worsened not improved. This once again has implications for policy makers as well as economic manager. A tiny minority stated that things have improved a lot and a total of only $10 \%$ stated that things have stayed the same way as they were before.

- $\quad$ Most people provided a very negative response and stated that inflation had skyrocketed to a huge extent. This has an important bearing on our previous discussion regarding how the index reflects the state of the economy. Therefore, $65 \%$ respondents stating that inflation had become very high gives a good description on the state of inflation in the country as a whole. Not a single respondent stated that inflation has either become less or very less. Most people either responded that inflation had become very high or reasonably high.

- $\quad$ On the question of unemployment, people expressed distinctly their views regarding future expectations about the state of unemployment. A huge $70 \%$ respondent stated their expectations that the unemployment will rise. Therefore, this question again has a negative judgment about the future expectations of people.

- A good $66 \%$ of people viewed these times to be bad times to spend on discretionary items.

\section{Scope for Future Research}

- $\quad$ This study, as mentioned above, also is a pioneer research that covers all the fields of business, be it economics, management or marketing. The implications of a consumer confidence index cover all areas and therefore are equally useful in each direction. A regularly conducted consumer survey will provide a benchmark upon which economic managers and policy makers of the country can evaluate their policies and correct them. It also provides an additional indicator to economists to monitor and forecast consumer spending. As stated by other authors, this index provides a good reflection of the state of the economy and can be used to support the more objective economic indicators.

- $\quad$ This survey must be conducted quarterly so as to be able to generate a time series, so that periodic swings of the measure could be recorded and analyzed. The extent to which the index has the ability to predict future spending can only be evaluated once time series data is at hand so that regression can be applied to it.

- $\quad$ The sample of 252 people, although statistically significant is still too small to be projected over a larger population. Therefore, regular consumer confidence survey should constitute a bigger sample. The sample used in ICS survey or $\mathrm{CCl}$ survey (500 and 5000 respectively) could be considered. The sampling methodology could be evaluated again and made more robust. 


\section{References}

Curtin, Richard. (2002), "Survey of Consumers: Theory Methods and Interpretations" Paper written for NABE 44th Annual Meeting, September 30.

De Boef, Suzanna and Kellstedt, Paul. (Oct., 2004) "The Political (And Economic) Origins of Consumer Confidence", American Journal of Political Science, Vol. 48, No. 4, pp. 633-649.

Desroches, Brigitte and Gosselin, Marc-André (Apr., 2004) "Evaluating Threshold Effects in Consumer Sentiment", Southern Economic Journal, Vol. 70, No. 4, pp. 942-952.

Duffy, David. and Williams, James., (April 2002) "Constructing a Consumer Sentiments Index for Ireland," IIB Bank Publication.

Fuhrer, Jeffery C. (1993) "What Role Does Consumer Sentiment Play in the US Macroeconomy?" New England Economic Review, January/February, pp. 32-44.

Ludvigson, Sydney. (Spring 2004), "Consumer Confidence and Consumer Spending", The Journal of Economic Perspectives, Vol. 18. No. 2. pp 29-50.

Mishkin, Frederic S. (1978) "Consumer Sentiment and Spending on Durable Goods" Brookings Paper on Economic Activity, Vol. 1, pp. 217-32.

Mueller, Eva. (Spring, 1966) "The Impact of Unemployment on Consumer Confidence", The Public Opinion Quarterly, Vol. 30, No. 1, pp. 19-32.

Pickering. J. F., Harrison, J. A., Cohen, C. D. (1973) "Identification and Measurement of consumer Confidence: Methodology and Some Preliminary Results" Journal of the Royal Statistical Society, Series A (General), Vol. 136, No. 1, pp. 43-63.

Potter, S. (1999). 'Fluctuations in confidence and asymmetric business cycles', Domestic Research Function, Federal Reserve Bank of New York. Staff report No. 66.

Roberts, Ivan. and Simon, John, (2001-09) "What do Sentiments Measure", Working Papers Series, Economic Research, Reserve Bank Of Australia.

Souleles, Nicholas. (Feb., 2004) "Expectations, Heterogeneous Forecast Errors, and Consumption: Micro Evidence from the Michigan Consumer Sentiment Surveys" Journal of Money, Credit and Banking, Vol. 36, No. 1, pp. 39-72.

Taylr, Karl and McNabb, Robert, (2007) "Business Cycles and Role of Confidence: Evidence from Europe", Oxford Bulletin of Economics and Statistics, Vol. 69, Issue 2, pp. $185-208$.

The Joint Harmonized EU Program of Business and Consumer Surveys- User Guide 
(Updated 2004), European Commission Directorate General, Business Surveys (ECFINA-3) Brussels.

Throop, Adrien W. (1992) "Consumer Sentiment: Its Causes and Effects." Federal Reserve Bank of San Francisco, Economic Review, pp. 35-59.

Zagórsk, Krzysztof and McDonnell, John, (1995) "Consumer Confidence Indexes as Social Indicators", Social Indicators Research, Vol. 36, No. 3. 


\section{APPENDIX}

Consumer Confidence Index Survey, Pakistan

\section{Aap kis shehar main rehtain hain ?}

- Karachi

- Lahore

- Islamabad

\section{Aap ki taleem kahan tak hai ?}

- Metric

- Intermediate

- Graduate

- Masters

- P.H.D

3. Aap ke ghar ki mahana amdani kitni hai

- $\quad<6000$

- $6000-12000$

- $12000-20000$

- 20000-40000

- 40000-100000

- 100000 above

4. Aap ke ghar main kitne log kamate hain?

- 1

- 2

- 3

- 4

- 5

- $>5$

5. Aap par apne ghar ke kitne logon ki zimmedari hai?

- $<4$

- 4

- 5 
$\begin{array}{ll}\text { - } & 6 \\ \text { - } & 7 \\ \text { - } & 8 \\ \text { - } & >8\end{array}$

6. Pichle bara mahenon main aap ke ghar ke mali halat man kia tabdeli aai hai ?

- Bohat behtar ho gai hai

- Kuch behtar hui hai

- Usi tarah hai

- Kuch kharab ho gai hai

- Bohat kharab ho gai hai

- Kuch keh nahin sakte

7. Aap ke andaze main agle bara mahenon main aap ke gharane ki halat main kis tarah ki tabdeli ka imkan hai

- Bohat behtar ho gai hai

- Kuch behtar hui hai

- Usi tarah hai

- Kuch kharab ho gai hai

- Bohat kharab ho gai hai

- $\quad$ Kuch keh nahin sakte

8. Aap ke andaze main pichle bara mahenon main mulk ke muashi halat main kia tabdeli aai hai ?

- Bohat behtar ho gai hai

- Kuch behtar hui hai

- Usi tarah hai

- Kuch kharab ho gai hai

- Bohat kharab ho gai hai

- $\quad$ Kuch keh nahin sakte

9. Aap ke andaze main agle ane wale bara mahenon main mulk ke muashi halat main kis tarah ki tabdeli aye gi ?

- $\quad$ Bohat behtar ho gai hai 
- Kuch behtar hui hai

- Usi tarah hai

- Kuch kharab ho gai hai

- Bohat kharab ho gai hai

- Kuch keh nahin sakte

10. Pichle bara mahenon main aam istemaal ki cheezon ki keemton main kia tabdeli aai hai?

- $\quad$ Bohat ziyada bar gai hain

- Khasi bar gai hain

- Mamooli si bar gai hain

- Koi tabdeli nahin aai

- Mamooli se kuch kum hui hain

- Khasi kum hui hain

- Bohat kum hui hain

- Kuch nahin keh sakte

11. Aap ke andaze main agle bara mahenon main aam istemaal ki cheezon ki keemton main kia tabdeli aye gi?

- Bohat ziyada tezi se barhain gi

- Isi raftar se barhain gi

- Is se kum raftar se barhain gi

- Koi tabdeli nahin aye gi

- Kum hon gi

- $\quad$ Kuch keh nahin sakte

12. Aap ke andaze main agle bara mahenon main mulk main berozgar logon ki tadad kia ho gi ?

- Bohat barh jaye gi

- $\quad$ Kuch bar jai gi

- Itni hi rahe gi

- Koi tabdeli nahin aye gi

- Kum hon gi

- $\quad$ Kuch keh nahin sakte 
13. Mulk ke muashi halat ko samne rakh kar bataiye ke kia yeh waqt bari bari cheezen (maslan: furniture,bigli,electronic ka saman waghera) kharedne ke liye munasib hai ya nahin ?

- Haan ye bilkul munasib waqt hai

- $\quad$ Na ye waqt munasib hai nag hair munasib

- $\quad$ Nahin ye munasib waqt nahin

- $\quad$ Kuch keh nahin sakte

14. Pichle bara maheenon ke muqable main aap ainda bara mahenon main bari bari cheezen (maslan: furniture,bigli,electronic ka saman waghera) ziyada kharede jayen ge ya aam ?

- Kafi ziyada cheezen kharedain ge

- Kuch ziyada cheezen khareedain ge

- Itni hi cheezen khareedain ge

- Kuch kum cheezen khareedain ge

- Kafi kum cheezen khareedain ge

- Kuch keh nahin sakte 